\title{
New training tools for new epidemiologists
}

\author{
Citation for published version (APA):
}

Arts, I. C. W., \& Weijenberg, M. (2013). New training tools for new epidemiologists. Environmental and Molecular Mutagenesis, 54(7), 611-615. https://doi.org/10.1002/em.21793

Document status and date:

Published: 01/08/2013

DOI:

10.1002/em.21793

Document Version:

Publisher's PDF, also known as Version of record

Document license:
Taverne

\section{Please check the document version of this publication:}

- A submitted manuscript is the version of the article upon submission and before peer-review. There can be important differences between the submitted version and the official published version of record.

People interested in the research are advised to contact the author for the final version of the publication, or visit the DOI to the publisher's website.

- The final author version and the galley proof are versions of the publication after peer review.

- The final published version features the final layout of the paper including the volume, issue and page numbers.

Link to publication

\footnotetext{
General rights rights.

- You may freely distribute the URL identifying the publication in the public portal. please follow below link for the End User Agreement:

www.umlib.nl/taverne-license

Take down policy

If you believe that this document breaches copyright please contact us at:

repository@maastrichtuniversity.nl

providing details and we will investigate your claim.
}

Copyright and moral rights for the publications made accessible in the public portal are retained by the authors and/or other copyright owners and it is a condition of accessing publications that users recognise and abide by the legal requirements associated with these

- Users may download and print one copy of any publication from the public portal for the purpose of private study or research.

- You may not further distribute the material or use it for any profit-making activity or commercial gain

If the publication is distributed under the terms of Article $25 \mathrm{fa}$ of the Dutch Copyright Act, indicated by the "Taverne" license above, 


\title{
Commentary
}

\author{
New Training Tools for New Epidemiologists \\ Ilja C.W. Arts ${ }^{1,2,3 *}$ and Matty P.Weijenberg ${ }^{1,4}$ \\ ${ }^{7}$ Maastricht Molecular Epidemiology Expertise group (M2E2), www.M2E2.nl, \\ Department of Epidemiology, Maastricht University, NL-6200 MD, Maastricht, \\ The Netherlands \\ ${ }^{2}$ CAPHRI School for Public Health and Primary Care, Maastricht University, \\ NL-6200 MD, Maastricht, The Netherlands \\ ${ }^{3}$ CARIM School for Cardiovascular Diseases, Maastricht University, NL-6200 \\ MD, Maastricht, The Netherlands \\ ${ }^{4}$ GROW School for Oncology and Developmental Biology, \\ Maastricht University, NL-6200 MD, Maastricht, The Netherlands
}

\begin{abstract}
Molecular epidemiology is moving from an era of single marker studies to omics-driven populationbased studies, made possible by recent rapid technological advances in high-throughput laboratory assays. The use of these assays in large, observational, epidemiologic studies poses major methodological challenges. The traditional, reductionist approach that most epidemiologists have been taught is no longer sufficient with the introduction of omics data into epidemiology. However, basic epidemiological principles, such as confounding, must still be addressed. In order to successfully implement these tools into molecular epidemiology, scientists in the required disciplines must be able to effectively communicate. We propose an interdisciplinary, three-level, problem-based approach to training in molecular epidemiology. This approach requires interdisciplinary teaching teams that appeal to students coming from diverse backgrounds. First, concepts from each field necessary

for molecular epidemiology must be addressed at a basic level, with a specific focus on biological, epidemiological, and statistical concepts. Second, state-of the art methods applied in molecular epidemiology should be covered (e.g., omics technologies, smart study designs, statistical modeling, and biological interpretation). Third, the application of omics technologies in population studies calls for awareness of issues related to biobanking, ethics, legislation, and public health. Problem-based learning is a useful tool for teaching when students need to apply complex concepts to complex situations as is the case in molecular epidemiology. Using this approach, students from diverse backgrounds work together to analyze problems, discuss, and exchange knowledge in modern molecular epidemiology. Training tools characterized by this approach will shape the molecular epidemiologists of the future. Environ. Mol. Mutagen. 54:61 1-615, 2013. (c) 2013 Wiley Periodicals, Inc.
\end{abstract}

Key words: teaching; molecular epidemiology; problem-based learning

\section{BACKGROUND}

Molecular epidemiology of chronic diseases is an innovative field of research in which molecular and biochemical concepts and techniques are incorporated into epidemiologic studies. Molecular epidemiology is moving from an era of single marker studies to omics driven population-based studies [Gerszten and Wang, 2008; Haring and Wallaschofski, 2012]. This is made possible by recent rapid technological advances in high-throughput laboratory assays that measure biomarkers in biological samples. Biomarker profiles may range from a limited number of targeted markers to a whole metabolome, and may include the measurement of (epi)genetic variation, gene expression, proteins, small molecules, and functional assays. Apart from genome-wide-association studies (GWAS), high-throughput laboratory assays have so far been used mostly in small-scale experimental studies. Their use in large, observational, epidemiologic studies is now rapidly increasing and poses major challenges to the scientific community [Thomas, 2005; Ioannidis, 2010].

Grant sponsor: Limburg University Fund/SWOL.

*Correspondence to: Dr. Ilja C.W. Arts, Department of Epidemiology, P.O. Box 616, NL-6200 MD, Maastricht, The Netherlands.

E-mail: M2E2@maastrichtuniversity.nl

Received 22 December 2012; provisionally accepted 17 May 2013; and in final form 18 May 2013

DOI 10.1002/em.21793

Published online 26 July 2013 in

Wiley Online Library (wileyonlinelibrary.com). 
First of all, epidemiology has been proven valuable to identify associations between exposure and disease, in particular, because it enables us to study long-term effects of "normal" variation in exposure in populations. Omics-type studies have so far paid little attention to environmental and lifestyle exposures. Although GWAS identified hundreds of genetic variants associated with diseases and genetic traits, most variability in human diseases is still not explained [Manolio, 2009], and exposure data are just beginning to become part of these studies [Aschard et al., 2012]. Novel concepts such as the "exposome," characterizing the totality of environmental exposures using omics technology, are currently being developed and incorporated in molecular epidemiology [Wild, 2012]. Other concepts, such as the meeting-in-the-middle approach, using omics to identify biomarkers linked to both exposure and outcome are important in getting the exposure data back into omicsbased epidemiological studies [Chadeau-Hyam et al., 2011]

Second, the traditional, reductionist, strongly hypothesis-driven approach that most epidemiologists are still being taught is failing with the introduction of large-scale omics measurements in population studies [Loscalzo, 2011]. Traditional epidemiology typically considers a limited number of exposures and outcomes, and makes no attempt to reveal the complex biological mechanisms that underlie these associations. Molecular epidemiology is developing novel methods, for example based on network theory [Barabasi et al., 2011] to adequately address these developments. We are moving from "black-box epidemiology" to "systems epidemiology" [Hu, 2011].

Third, while omics-based epidemiological studies may require new approaches, basic epidemiological principles such as confounding, interaction, selection of the population, and measurement error are still extremely important [Rundle et al., 2012]. Bias is just as likely to occur in molecular epidemiology studies as in traditional epidemiology studies, but it is often not addressed adequately in current studies incorporating omics measurements [Rundle et al., 2012].

Because the development of omics has so far been largely technology-driven and stems from laboratory research, epidemiologists have been insufficiently involved in studies incorporating omics measurements. A major risk is that the technology becomes the driving force of research, instead of a tool for epidemiology. We argue that interdisciplinary collaboration, involving adequately trained epidemiologists, laboratory researchers, biostatisticians, mathematicians, and bioinformaticians who are aware of epidemiological methods is the only way to move the field forward. So how can training in molecular epidemiology contribute to this?

\section{APPROACH}

We propose an interdisciplinary, three-level, problembased approach to training in molecular epidemiology, and have applied this approach in a 5-day postgraduate course on molecular epidemiology of chronics diseases (www.M2E2.nl).

\section{Interdisciplinary Collaboration}

When introducing omics in population studies, interdisciplinary collaboration is necessary to ensure valid results. Scientists from multiple disciplines need to understand each other's languages and techniques. This has consequences for training in molecular epidemiology with respect to both teaching staff and students. Interdisciplinary teams are needed in teaching molecular epidemiology. Furthermore, the teaching needs to appeal to students coming from diverse areas of research such as pathology, molecular biology, genetics, analytical chemistry, statistics, bioinformatics, general public health, and traditional epidemiology. The teaching thus needs to be adapted to these diverse backgrounds and diverse entrance levels of the students in the fields that are required for molecular epidemiology.

\section{Three-Level Approach}

Because of this heterogeneity in students, we propose a three-level approach to training (Fig. 1). First, concepts from each field necessary for molecular epidemiology need to be addressed at a basic level, specifically, biological, epidemiological, and statistical concepts. We have implemented this by organizing parallel sessions which the course participants could attend depending on their basic training. Second, state-of the art methods applied in molecular epidemiology should be covered. These include the different -omics technologies, the quality control of complex raw data, smart study designs that are costeffective, valid, and of sufficient power, exploratory, pathway-based and multivariate regression modeling techniques, bioinformatics tools, and the biological interpretation of findings. Students may have basic knowledge on these topics, depending on their basic training. This makes this level particularly suitable for students to "teach each other." Third, the application of -omics technologies in population studies calls for awareness of issues related to biobanking, ethics, legislation, and public health implications.

No two molecular epidemiology studies are exactly the same. This is because they are usually embedded in ongoing longitudinal population-based studies, because of the difficulty in assessing exposures in large populations in sufficient detail, and because of the complexity of collecting and storing biological samples for long periods of time. Molecular epidemiologists therefore 

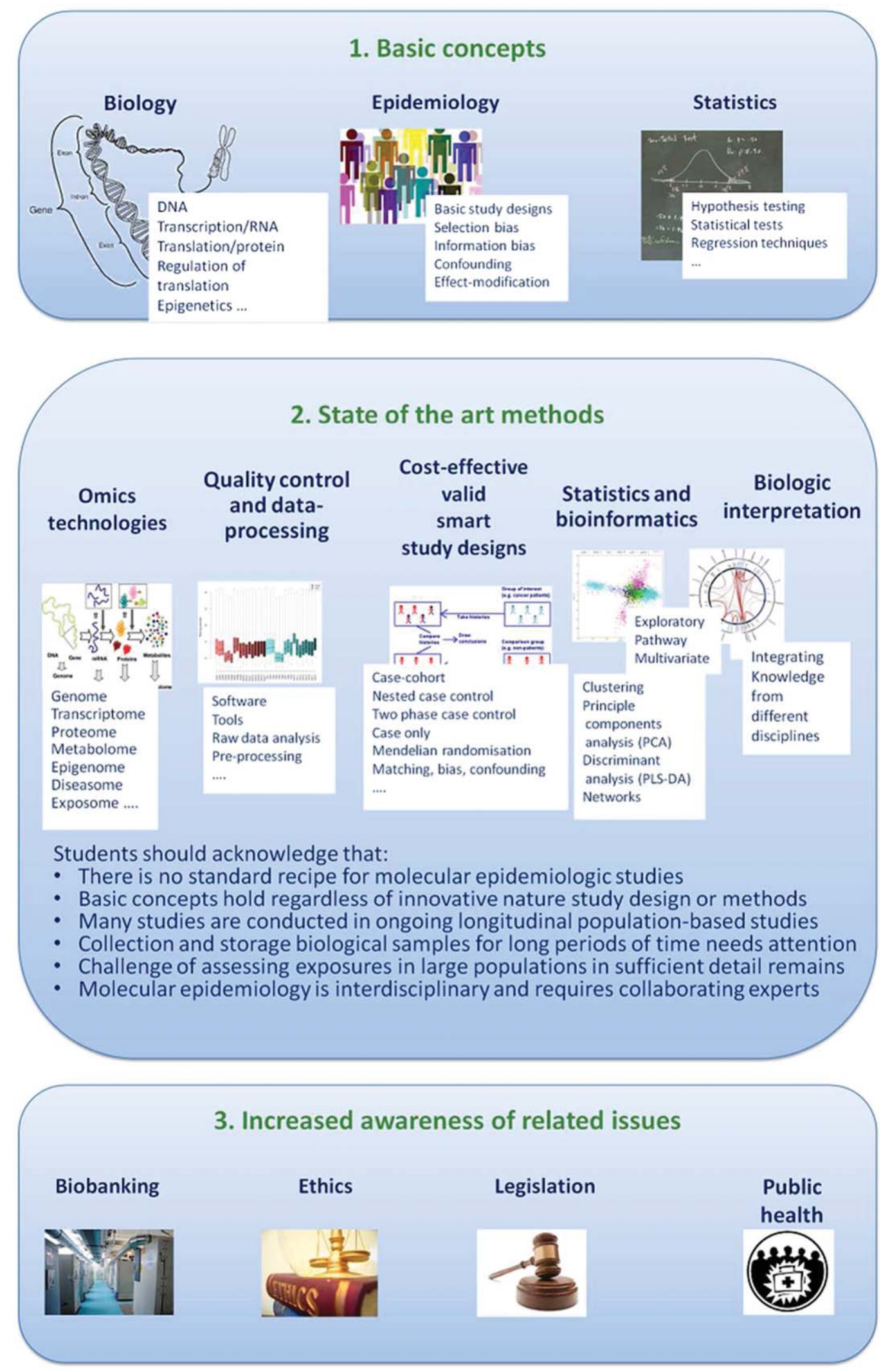

Fig. 1. The interdisciplinary, three-level, problem-based approach to training in molecular epidemiology. 
should be trained to deal with diverse methodological issues which have to be adapted tailor-made to the situation at hand.

\section{Problem-Based Learning}

Problem-based learning is a useful tool for teaching when students need to apply complex concepts to complex situations as in interdisciplinary fields like molecular epidemiology. In small tutorial groups composed of students from diverse backgrounds they analyze problems, discuss, and exchange knowledge. By actively addressing a number of cases students better grasp the underlying concepts and learn to apply their insights to various situations. Problem-based learning encompasses four basic learning principles. Constructive learning facilitates understanding and leads to better recall of information through activation of prior knowledge and elaboration [Chi, 2009]. Contextual learning facilitates retrieval of knowledge through acquiring new knowledge in the context of multiple situations and disciplines [Bransford and Schwartz, 1999]. Collaborative learning is the result of in-depth interactions in groups around complex problems and leads toward conceptual changes in the student's thinking and better learning [Springer et al., 1999; Chi, 2009]. Finally, through self-regulated learning students play an active role the in planning, monitoring, and evaluation of their learning, resulting in better achievements [Ten Cate et al., 2011]. We have used problem-based learning particularly in the second level of the course. Because in this phase all students have a basic level of understanding of the concepts relevant in molecular epidemiology, but knowledge on the advanced issues varies considerably between students, depending on their basic training. For example, we provide groups of approximately six students from diverse backgrounds with a description of a study in which only a limited budget is available for omics measurements. As a group they have to come up with the best study design, and present this to the larger group. Both students and faculty ask questions and provide feedback.

\section{CONCLUSION}

Both molecular epidemiologic research and training are by definition collaborative efforts. The Maastricht Molecular Epidemiology Group (M2E2) has developed an international course "Molecular epidemiology of chronic diseases" which was designed according to the proposed interdisciplinary, three-level, problem-based approach to training. We have now successfully run this course for two years in a row. Students indeed came from very diverse backgrounds, such as traditional epidemiology, social sciences, molecular biology, biostatistics, bioinformatics, and psychology. The approach was highly appreciated by all participants, although it remains difficult to "learn each other's language" in a week. Such training tools should therefore be regarded foremost as a means to create awareness of problems and solutions in other fields of research and to create networks from which interdisciplinary research groups may grow. Training tools characterized by this approach will shape the molecular epidemiologists of the future.

\section{ACKNOWLEGEMENTS}

Authors are grateful to the interdisciplinary group of experts who helped to shape ideas on training in molecular epidemiology, in particular they would like to thank: Prof. dr. Stefano Bonassi (IRCCS San Raffaele Pisana, Rome, Italy), Prof. Dr. Paolo Vineis (Imperial College, London, UK), Prof. Dr. Kristel Van Steen (Univ. of Liège, Liège, Belgium), Prof. Dr. Tomasz Burzykowski (I-BioStat, Hasselt Univ., Hasselt, Belgium), Prof. Dr. Angela Brand (Inst. Public Health Genomics, Maastricht Univ.), Dr. Theo de Kok (Dept. Toxicogenomics, Maastricht Univ.), Dr. Roger Godschalk (Dept. Toxicology, Maastricht Univ.), Dr. Lars Eijssen (Dept. Bioinformatics, Maastricht Univ.), Dr. Valeria Limapassos (Dept. Methodology \& Statistics, Maastricht Univ.), and Dr. Rachel Cavill (Dept. Toxicogenomics, Maastricht Univ.).

\section{REFERENCES}

Aschard H, Lutz S, Maus B, Duell EJ, Fingerlin TE, Chatterjee N, Kraft P, Van Steen K. 2012. Challenges and opportunities in genomewide environmental interaction (GWEI) studies. Hum Genet 131: 1591-1613.

Barabasi AL, Gulbahce N, Loscalzo J. 2011. Network medicine: A network-based approach to human disease. Nat Rev Genet 12: 56-68.

Bransford JD, Schwartz DL. 1999. Rethinking transfer: A simple proposal with multiple implications. Rev Res Educ 24:61-100.

Chadeau-Hyam M, Athersuch TJ, Keun HC, De Iorio M, Ebbels TM, Jenab M, Sacerdote C, Bruce SJ, Holmes E, Vineis P. 2011. Meeting-in-the-middle using metabolic profiling-A strategy for the identification of intermediate biomarkers in cohort studies. Biomarkers 16:83-88.

Chi MTH. 2009. Active-constructive-interactive: A conceptual framework for differentiating learning activities. Top Cogn Sci 1: 73-105.

Gerszten RE, Wang TJ. 2008. The search for new cardiovascular biomarkers. Nature 451:949-952.

Haring R, Wallaschofski H. 2012. Diving through the "-omics": The case for deep phenotyping and systems epidemiology. Omics 16: 231-234.

Hu FB. 2011. Metabolic profiling of diabetes: From black-box epidemiology to systems epidemiology. Clin Chem 57:1224-1226.

Ioannidis JP. 2010. Expectations, validity, and reality in omics. J Clin Epidemiol 63:945-949.

Loscalzo J. 2011. Systems biology and personalized medicine: A network approach to human disease. Proc Am Thorac Soc 8: 196-198.

Manolio TA. 2009. Finding the missing heritability of complex diseases. Nature 461:747-753. 


\section{Environmental and Molecular Mutagenesis. DOI 10.1002/em}

Rundle A, Ahsan H, Vineis P. 2012. Better cancer biomarker discovery through better study design. Eur J Clin Invest 42:1350-1359.

Springer L, Stanne ME, Donovan SS. 1999. Effects of small-group learning on undergraduates in science, mathematics, engineering, and technology: A meta-analysis. Rev Educ Res 69:21-51.

Ten Cate TJ, Kusurkar RA, Williams GC. 2011. How self-determination theory can assist our understanding of the teaching and learning processes in medical education. AMEE Guide No. 59. Med Teach 33:961-973.

Thomas DC. 2005. The need for a systematic approach to complex pathways in molecular epidemiology. Cancer Epidemiol Biomarkers Prev 14:557-559.

Wild CP. 2012. The exposome: From concept to utility. Int J Epidemiol 41:24-32. 